\title{
Influence of Reproduction and Basal Area on the Increment of Euterpe edulis
}

\author{
Juliano Zago da Silva ${ }^{1}$ (1) 0000-0001-6296-0814 \\ Miguel Busarello Lauterjung ${ }^{1}$ (1) 0000-0003-1300-7773 \\ Maurício Sedrez dos Reis ${ }^{1}$ (D) 0000-0002-1486-0242
}

\begin{abstract}
The diameter increments of Euterpe edulis was characterized in order to understand the influence of reproduction and forest basal area on its growth and to represent its development through polynomial models. For up to 14 years three populations were studied using permanent plots. To identify the effect of reproduction, the diameter increments of young and reproductive palms, as well as the effect of productivity on growth, were compared. To characterize the effect of basal area, subpopulations under different basal area conditions were compared, as was the effect of their evolution over time. Reproductive activity and forest basal area interfered with plant growth, being smaller in more productive plants and under more advanced successional conditions. Fifth-degree models were more suitable for ecological studies or for fruit harvesting. Quadratic models were restricted to estimates of palm heart management.
\end{abstract}

Keywords: growth models, palm heart, fruits, non-timber forest product.

\section{INTRODUCTION AND OBJECTIVES}

Euterpe edulis (Martius) is a shade-tolerant climatic species, belonging to the family Arecaceae, with a natural occurrence in the Brazilian Atlantic Forest (Klein, 1980). According to the same author, in the secondary succession processes, it settles in the forest during the Miconietum stage, occupying the medium understory and standing out as one of the most abundant tree species. For a long time, it was the main tree used for palm heart production in the southern and southeastern Brazilian regions, which became a target of intense exploitation and, consequently, threatened with extinction (Brasil, 2014). Nowadays, in addition to serving as a raw material for palm heart harvesting, its fruits are also used as a local substitute for açaí (Euterpe oleracea and Euterpe precatoria). Fruit harvesting has been considered a more sustainable option, since palm heart harvesting requires the cutting and death of the plant (Trevisan et al., 2015).

Considering the importance of this species as a supplier of non-timber forest products (palm heart and fruits), the development of sustainable management strategies that value forests through their use may be an alternative for their conservation. In this perspective, E. edulis has been studied as a model for the Atlantic Forest, including demographic studies (Cappelatti \& Schmitt, 2015; Portela et al., 2010), growth of individuals' - increment (Fantini \& Guries, 2007; Reis et al., 1999, 2000), natural regeneration dynamics (Muler et al., 2014; Neuburger et al., 2010), phenology (Paludo et al., 2012; Silva \& Reis, 2018), seed germination (Leite et al., 2012), dispersal (Galetti et al., 2013; Silva \& Reis, 2019), and population genetics (Konzen \& Martins, 2017; Silva \& Reis, 2010).

In a proposal for sustained management, according to Fantini et al. (1992), three factors must be considered to guarantee sustainability: the available stock evaluation, the increment rates, and the natural regeneration of the explored species. Among these factors, few studies have focused on the characterization of increment rates (Fantini \& Guries, 2007; Reis et al., 1999, 2000); therefore, little is yet known.

The stipe diameter increases by enlargement and parenchyma division, as well as by meristematic action giving rise to vascular bundles and parenchyma (Botânico \& Angyalossy, 2013). This growth measure is a very important

${ }^{1}$ Universidade Federal de Santa Catarina (UFSC), Florianópolis, SC, Brasil 
parameter, since it allows the current annual increments (CAI) determination, plant development evaluation over time, and estimation of the number of individuals that can be exploited (Reis et al., 2000). In addition, the functional relationship between diameter at breast height (DBH, $1.3 \mathrm{~m}$ ) and CAI can estimate the individual and collective plants' growth and establish intervention intervals, such as cutting for the palm heart harvest (Reis et al., 2000), or predicting plant productivity, in the case of fruit harvesting (Paludo et al., 2012; Silva \& Reis, 2018). Due to the plant's long-life cycle, short-term studies assessments are usually limited. Consequently, this measure is often used for extrapolations over time, which introduces errors and scarcely captures the variation between ontogenetic stages.

The mathematical models tested for the DBH increment in E. edulis give a better fit to quadratic polynomials without a constant (Reis et al., 1999, 2000), indicating a greater increment between the classes of 6 and $10 \mathrm{~cm}$ for DBH and for cut limit diameter (CLD), between 7 and $9 \mathrm{~cm}$ of DBH. The CLD refers to the point of maximum increment of each equation, which allows the identification of the minimum diameter at which a plant should be cut, aiming at better use of its growth potential (Reis et al., 1999, 2000).

The objective of this study was to characterize the current annual increment of $E$. edulis from long-term studies, in order to improve the accuracy of diameter growth estimates using polynomial models, as well as to identify and understand the influences of reproductive maturation and the basal area of the forest on the increment in different populations. This information will be useful for both sustainable fruit harvesting and palm heart cutting. This study also presents applications in sustainable management, because growth rate reduction may coincide with the beginning of the reproductive phase. In this sense, following the CLD alone could be dangerous in the long-term, as it may lead to the cutting of plants before they reproduce and, therefore, contribute to genetic and demographic maintenance.

\section{MATERIALS AND METHODS}

This study was carried out in three areas of the Dense Ombrophylous Forest in the State of Santa Catarina, located in the municipalities of Ibirama, São Pedro de Alcântara, and Florianópolis. All areas are in a Cfa climate region and are classified in the advanced stage of secondary succession (Brasil, 1994). However, their use and exploration history differ, with emphasis on clear cutting, agricultural use and the gradual abandonment of agriculture in the areas of São Pedro and Florianópolis, and selective cutting in Ibirama (last recorded in 1970).
The area located in Ibirama is in the National Forest of Ibirama/ICMBio (Flona). On this site, 24 permanent plots $40 \times 40 \mathrm{~m}$ (3.84 ha) in area were evaluated between 1997 and 1998, between 2002 and 2008, and in 2010 - ten evaluations in 14 years. Among the evaluated areas, this is the one with the highest population of E. edulis, larger classes of DBH, and more seedlings. The basal area of this forest in 2006 was $36.5 \mathrm{~m}^{2} /$ ha $(6.3$ E. edulis +30.2 woody tree species), with mean DBH of $14.7 \mathrm{~cm}$, diameters up to $140 \mathrm{~cm}$ of DBH and a presence of large numbers of climax species (ICMBio, 2008). For these reasons, the most conserved area can be considered.

In the area located in São Pedro de Alcântara (SPA), six permanent plots of area $50 \times 50 \mathrm{~m}$ (1.5 ha) were planted, of which four (A to D) are located in a more advanced stage of regeneration, classified as Mata Secundária (MS), and two ( $\mathrm{E}$ and F), are in an earlier stage, classified as Miconietum (MI) (Klein, 1980). These plots were characterized by Mantovani et al. (2005), who recorded, in the MI portion, a predominance of pioneer and opportunistic species, more plants, lower species richness, an average $\mathrm{DBH}$ of $12.0 \mathrm{~cm}$, diameters of less than $40 \mathrm{~cm}$, and the recruitment of climax species. In the most advanced portion (MS), absent climax species under MI conditions were recorded, an average of $15.6 \mathrm{~cm}$ for $\mathrm{DBH}$, up to $90 \mathrm{~cm}$. In addition to this characterization, the basal area of the woody tree species $(\mathrm{DBH} \geq 5 \mathrm{~cm})$ present in these plots was evaluated annually between 1994 and 2000 (seven years), by Mantovani (unpublished data), and were used for comparison purposes in the present study. The mean basal area values for the period were $34.63 \pm 1.33 \mathrm{~m}^{2} / \mathrm{ha}$ for MS (32.02 \pm 1.13 woody tree species and $2.61 \pm 0.24 E$. edulis) and $30.65 \pm 0.99 \mathrm{~m}^{2} / \mathrm{ha}$ for the MI stage $(26.19 \pm 0.95$ woody tree species and $4.45 \pm 0.57$ E. edulis). The plots were implemented in 1991 and evaluated annually between 1992 and $2004-13$ evaluations in 13 years.

The area located in Florianópolis is in the Desterro Environmental Conservation Unit (UCAD). In this area, from 1999 to 2004 and from 2007 to 2008, six permanent plots of $40 \times 40 \mathrm{~m}$ ( $0.96 \mathrm{ha}$ ) were evaluated - eight evaluations in ten years. Among the study areas, this population was the most recently explored, with signs of plant cutting in 1999. The mean basal area of $E$. edulis for the evaluation period was $0.47 \pm 0.8 \mathrm{~m}^{2} / \mathrm{ha}$, with no information on the basal area of the other woody tree species.

In all the studied areas, E. edulis plants that presented stipe exposed to $1.3 \mathrm{~m}$ were mapped, labeled, and evaluated for the DBH and phenology. The new plants were included in each evaluation and monitored in subsequent evaluations. The growth (current annual increment - CAI) was determined by the difference between the DBH measures presented by the plants between the different years of study 
[CAI: $\left(\mathrm{DBH}_{\text {at the end of the period }}-\mathrm{DBH}_{\text {at the beginning of the period }}\right) /$ period's duration in years].

The relationships between the basal area of the forest and the incremental rates of E. edulis were tested by Pearson's correlation analysis and by data fitting to the linear model according to the following criteria: 1) significance of the coefficients, obtained in a parsimonious way; 2) random distribution of residues; 3 ) adjusted $\mathrm{R}^{2}$ value; and 4 ) the significance of the models. For these estimates, only the studied areas in S. P. Alcântara were used, due to the availability of data on the annual assessment of woody tree species conducted by Mantovani (unpublished data). In this sense, each one of the six plots were used as a pair of data points (presenting annual values of basal area for woody tree species and CAI for E. edulis), resulting in 42 data points used for regression.

The evaluation of the effect of reproductive activity on plant growth was based on two tests. The first one was to verify whether there was a decrease in the increment after the plants came into reproduction, presupposing that resources would be preferentially allocated to the formation of the reproductive structures rather than to vegetative growth. The rates of young and reproductive plants' increment in different classes of DBH and those of young and reproductive plants in the total set were compared, using $95 \%$ confidence intervals. In these comparisons, data from the populations of São P. Alcântara and Ibirama, obtained during the entire evaluation period (13 and 14 years, respectively) were used. The population present in Florianópolis was not compared due to the small number of reproductive palms found there.

The second test was performed to verify the number of inflorescences emitted per reproductive palm (productivity) and whether it would affect the increment rates, assuming that: the higher the reproductive investment, the lower the vegetative growth. For this, Pearson's correlation coefficient was calculated, and comparisons between the average increments presented by the different productivity classes (one, two, three, four, five, or six inflorescences emitted) using $95 \%$ confidence intervals were made. For these tests, data obtained on the Ibirama population were used, where all the reproductive palms' phenology (888) present in the 24 plots was considered. The monitoring took place monthly between May 2007 and December 2008, registering the number of inflorescences emitted for each reproductive palm.

For the estimates of increment (CAI), polynomial models were evaluated using the Microsoft Excel program. This study tested for second-degree polynomials (Equation 1), considering its indication for E. edulis (Reis et al., 1999, 2000) and for other tree species (Spathelf et al., 2001); this study also tested for higher-degree polynomials (three to six) (Equation 2), with and without a constant $(\beta 0)$. $\beta$ represents the estimated parameters.
Examples:

Degree 2: $\mathrm{CAI}=\beta_{0}+\beta_{1}{ }^{\star} \mathrm{DBH}+\beta_{2}{ }^{\star} \mathrm{DBH}^{2}$

Degree 6: $\mathrm{CAI}=\beta_{0}+\beta_{1}{ }^{\star} \mathrm{DBH}+\beta_{2}{ }^{\star} \mathrm{DBH}^{2}+\beta_{3}{ }^{\star} \mathrm{DBH}^{3}+$ $\beta_{4}{ }^{\star} \mathrm{DBH}^{4}+\beta_{5}{ }^{\star} \mathrm{DBH}^{5}+\beta_{6}{ }^{\star} \mathrm{DHB}^{6}$

The regressions were constructed based on the mean increment of each diameter class, at $1 \mathrm{~cm}$ intervals of DBH. Because the forests have uneven ages, the $\mathrm{DBH}$ values were treated as independent variables, treating plant age as variable and unknown, as already done by other studies (Reis et al., 1999, 2000; Spathelf et al., 2001; Scheeren et al., 2003). The evaluation of model adjustment followed the criteria presented for modeling applied to the basal area.

\section{RESULTS AND DISCUSSION}

\subsection{Euterpe edulis increment and influence of the forest's basal area}

The current annual incremental values (CAI) of E. edulis in different populations are presented in Figure 1. According to this figure, even with significant differences among populations regarding CAI values, the plants presented the same pattern of growth: they started with increasing increment rates until they reached a maximum (between six and ten cm of DBH - corroborating Reis et al., 1999, 2000), and from this point onwards, a reduction and subsequent stabilization occurred at a growth rate close to that observed for 2 and $3 \mathrm{~cm}$ DBHs, lasting until the end of the individual's life. In general, the increment values presented by the different DBH classes approximated a curve with positive asymmetry, which was more evident in conserved populations as the Figure $1 \mathrm{~b}$ shows.

The greatest differences in CAI values were observed within the SPA population as shown in Figures 1a and 1c, indicating the influence of the successional condition on the growth rates of $E$. edulis. This influence is possibly related to the lower forest cover, which offers more light and space for E. edulis to grow (Fantini \& Guries, 2007). This aspect is reinforced by the comparison of subareas located in SPA represented in Figures 1a and 1c, mainly because they are part of the same fragment, where the sample sets are close (about $200 \mathrm{~m}$ ), decreasing influences related to climate and soil conditions and highlighting the structural differences observed by Mantovani et al. (2005). These results are also corroborated by Granville (1991), who classified erect and single-stemmed palms as adapted to canopy openings and frequent in disturbed areas, which has been confirmed for 
the E. precatoria congener (Avalos, 2016). The availability of light has been reported as a limiting factor to the neotropical palms' growth and reproduction (Ninazunta et al., 2016; Svenning, 2002), and its influence has been observed on the survival and development of E. edulis seedlings (Guimarães et al., 2018; Ribeiro et al. al., 2011).

The variations in the basal area values of woody tree species (without E. edulis) and CAI of E. edulis over the years in SPA (1994 to 2000) were correlated ( $\mathrm{r}:-0.63 ; \mathrm{n}: 42 ; \mathrm{p}<0.01$ ), indicating less growth in diameter with increasing basal area, demonstrated by Figure 2. The intermediate positioning of CAI values for the Ibirama population in relation to SPA

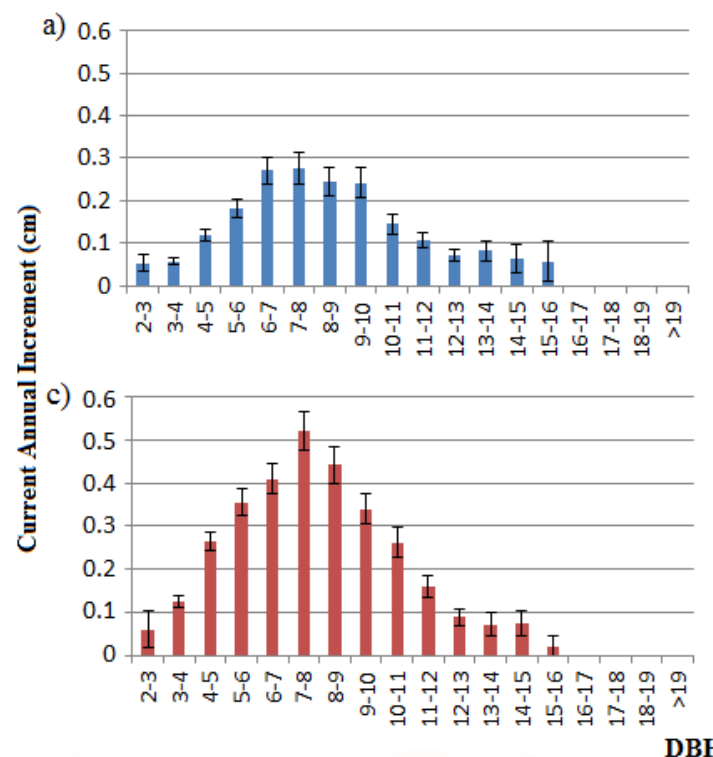

DBH classes $(\mathrm{cm})$

Figure 1. Current annual increment values per diameter class (DBH) for different Euterpe edulis populations. (a) São Pedro de Alcântara subarea Mata Secundária, n: 5,591; (b) Flona-Ibirama, n: 24,205; (c) São Pedro de Alcântara subarea Miconietum, n: 4,537; and (d) UCADFlorianópolis, n: 477. Error bars indicate 95\% confidence intervals.

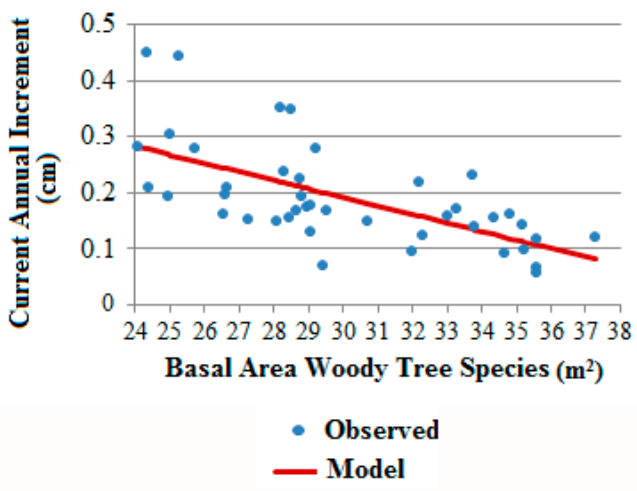

Figure 2. Euterpe edulis current annual increment for the São Pedro de Alcântara population during the years 1994 and 2000 in relation to the evolution of the basal area of woody tree species. CAI: $0.649092217-$ $0.01526426^{\star} \mathrm{AB}, \mathrm{R}^{2}$ adjusted: $0.39, p$ for model and coefficients: $<0.0001$. sub-areas also reinforces these arguments represented in Figures $1 \mathrm{a}, \mathrm{b}$ and $\mathrm{c}$, because its basal area $\left(30.2 \mathrm{~m}^{2} / \mathrm{ha}\right)$ shows an intermediate condition to that observed for SPA sub-areas (MS: $32.02 \mathrm{~m}^{2} / \mathrm{ha}$ and MI: $26.19 \mathrm{~m}^{2} / \mathrm{ha}$ ).

The earliest stages evaluated, with basal areas between 24 and $30 \mathrm{~m}^{2} / \mathrm{ha}$ for the woody tree species as shown in Figure 2, presented the greatest variations regarding the CAI values, indicating the influence of other factors and the possibility of management to support faster growth. This confirms the results obtained by Fantini \& Guries (2007), who also observed reductions in the increment of $E$. edulis with increasing forest's basal area and greater variation in lower basal areas.

b) 0

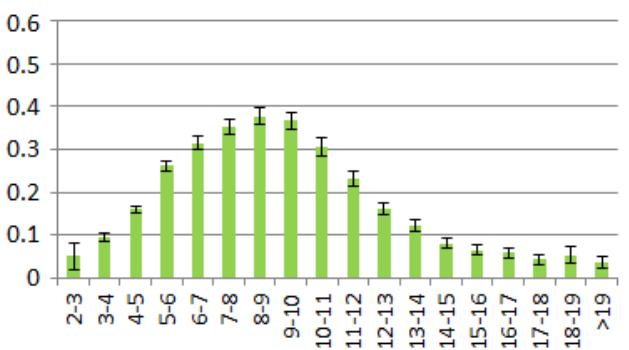

d) 0

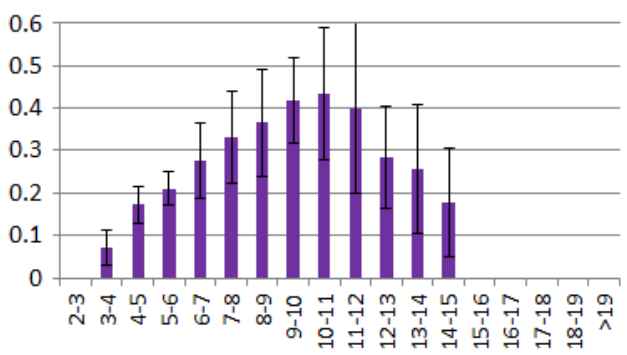

UCAD - Florianópolis

\subsection{Influence of reproduction on increment rates}

The reduced vegetative growth (height, diameter, and leaf emission) during the reproductive period and the costs of reproduction have been shown in dioecious palms, where female plants tend to show less development than male plants (Cepeda-Cornejo \& Dirzo, 2010; Edwards et al., 2015). In the monoic palms - such as E. edulis - the cost of reproductive activity has been poorly reported, although it has already been recorded for other genera (Ninazunta et al., 2016; Souza et al., 2003) and trees (Thomas, 2011).

The evaluations performed in this study indicated a gradual increase in the reproductive palms' proportion represented in Figure 3 after the diametric classes with the 
highest increment ( 6 to $10 \mathrm{~cm}$ ) exposed in the Figure 1, suggesting a negative effect of reproduction on growth, in diameter terms. However, growth comparisons between young and reproductive plants after the peaks of greater increment as in the Figure 4, revealed reductions in the increment rates of both ontogenetic stages, although these reductions were much greater in reproductive palms. The reduction of vegetative growth has been associated with changes in the resource allocation form and the prioritization of reproductive structures (Cepeda-Cornejo \& Dirzo, 2010; Edwards et al., 2015; Thomas, 2011). This could even be occurring with plants classified as young, after the highest increment peaks, possibly due to a classification error, since losses/abortions can occur in very early stages, while the structures are covered by leaf sheaths.

Considering the hypothesis that the formation of the reproductive structures hinders the growth rate, the number of inflorescences emitted by the reproductive palm was related to its CAI. These results indicate that the higher the number of reproductive structures emitted by the palm as shown in Figure 5, the lower the CAI values presented ( $\mathrm{r}:-0.89, \mathrm{n}: 6$, $\mathrm{p}<0.05)$. In this sense, it should be noted that the reduction in CAI rates after the highest growth peaks (6 to $10 \mathrm{~cm}$ of $\mathrm{DBH}$ ) is related not only to the reproductive activity but also to the productivity presented by palms.

Because reproductive activity reduces the $\mathrm{DBH}$ growth, the greatest increment peak position in a population may be related to the relative proportions of young and reproductive plants, as well as the stimulus to begin reproduction. This phenomenon appears to occur in the SPA population demonstrated in Figures $1 \mathrm{a}$ and $1 \mathrm{c}$, where, for some unknown reason, the reproductive phase begins before the other populations as shown in Figures 3a and $3 c$, or even with the population of the UCAD exhibited in the Figure $3 \mathrm{~d}$, because the small reproductive palms proportion (11.9\%), could be shifting the peaks of higher increment to higher DBH classes, as expressed in Figure 1d.
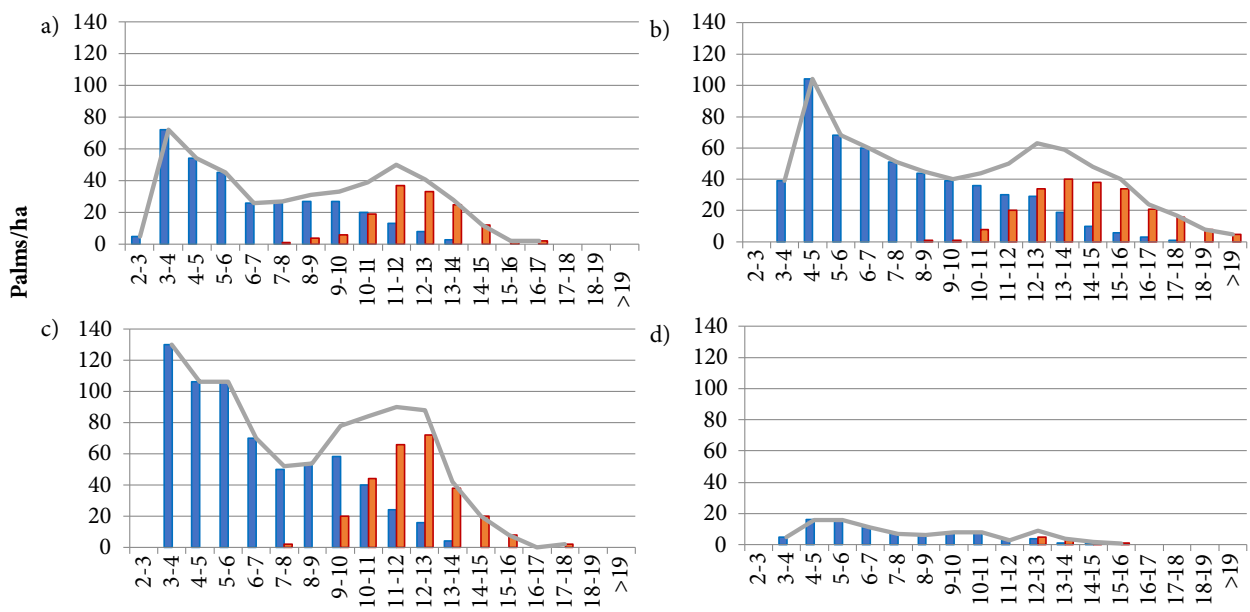

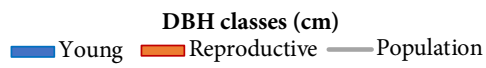

Figure 3. Young and reproductive palms' population diameter distribution in three study areas in the State of Santa Catarina: (a) São Pedro de Alcântara Mata Secundária; (b) Flona of Ibirama; (c) São Pedro de Alcântara Miconietum; and (d) UCAD in Florianópolis.

a)

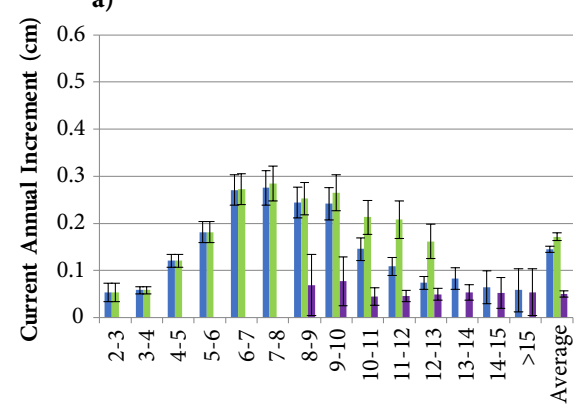

b)

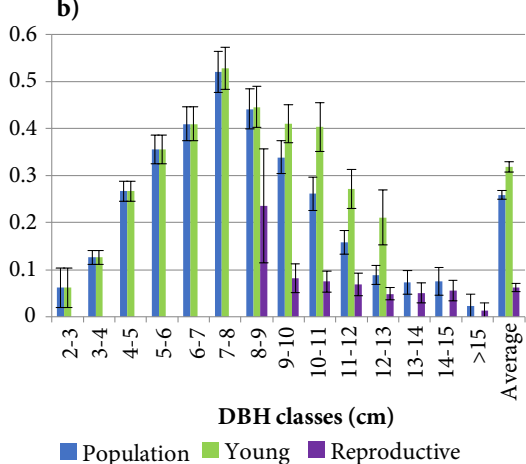

c)

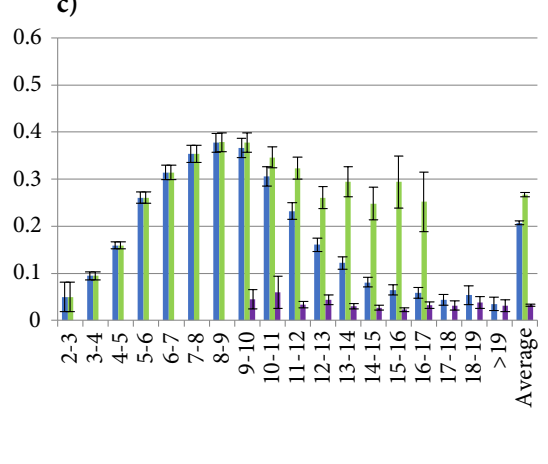

Figure 4. Young and reproductive palms' current annual increment, and for populations as a whole in the study areas of: (a) São Pedro de Alcântara Mata Secundária; (b) São Pedro de Alcântara Miconietum; and (c) Ibirama. Error bars indicate $95 \%$ confidence intervals. 


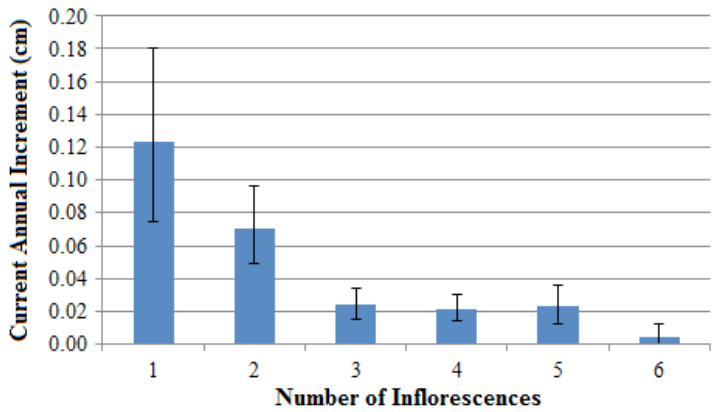

Figure 5. Relationship between the reproductive structures' number emitted by palm and its current annual increment in $\mathrm{DBH}$ for the Ibirama population. Error bars indicate $95 \%$ confidence intervals.

\subsection{Modeling of current annual increment values}

The applied model indicated better results for the fifth-degree polynomial models, with and without a constant for the SPA and Ibirama populations as represented in Figures 6 a1, a2, and a3. However, for the population present in the UCAD, quadratic polynomial models with a constant presented better results as shown in the Figure $6 \mathrm{a} 4$, approaching the results obtained by Reis et al. $(1999,2000)$ for E. edulis.

The equations referring to the best obtained models are described below (Equations 3 to 6). The residues' distribution is shown in Figures 6c, 1 to 4.

$\mathrm{CAI}_{\text {Ibirama }}:-0.124560$ * $\mathrm{DBH}+0.070694$ * $\mathrm{DBH}^{2}-0.009573$ *

$\mathrm{DBH}^{3}+0.000496 * \mathrm{DBH}^{4}-9 \times 10^{-6 *} \mathrm{DBH}^{5}$

$\mathrm{R}^{2}$ adjusted: $0.92 ; p$ for model and coefficients: $<0.0001$; standard error: 0.015 .

$\mathrm{CAI}_{\text {SPA-MS }}: 1.116356-0.926165 * \mathrm{DBH}+0.279591 * \mathrm{DBH}^{2}-$ 0.035418 * $\mathrm{DBH}^{3}+0.001992 * \mathrm{DBH}^{4}-4 \times 10^{-5 *} \mathrm{DBH}^{5}$

$\mathrm{R}^{2}$ adjusted: $0.97 ; p$ for model and coefficients: $<0.001 ; p$ for constant: $<0.003$; standard error: 0.015 .

$\mathrm{CAI}_{\text {SPA-MI }}:-0.260250 * \mathrm{DBH}+0.149404 * \mathrm{DBH}^{2}-0.022887$

$\star \mathrm{DBH}^{3}+0.001374 * \mathrm{DBH}^{4}-0.000029 * \mathrm{DBH}^{5}$

$\mathrm{R}^{2}$ adjusted: 0.88 ; $p$ for model and coefficients: $<0.001$; standard error: 0.032 .
$\mathrm{CAI}_{\mathrm{UCAD}}:-0.446414+0.173761$ * $\mathrm{DBH}-0.008957 * \mathrm{DBH}^{2}(6)$

$\mathrm{R}^{2}$ adjusted: 0.93 ; $p$ for model, coefficients and constant: $<0.0001$; standard error: 0.029 .

The difference in agreement of second- or fifth-degree polynomial models was related to the capacity to describe the growth observed in the larger classes of $\mathrm{DBH}$. Thus, the higher the number of reproductive palms and the larger the diameter classes, the greater the positive asymmetry presented by the CAI curves, and quadratic polynomial models are less adequate. This lower agreement is related to the fact that the growth curve of reproductive palms does not pass through the origin and is not reduced so abruptly as described in quadratic polynomial models as shown in Figures 6 b1, b2, and b3 but displays a smoother stabilization at a rate of increment of about $0.05 \mathrm{~cm}$ per year represented in Figures 6 a1, a 2 and a3. In this sense, since quadratic polynomial models do not allow as many curves, the attempt to adjust to the growth presented by the larger classes of DBH forces its vertical flattening, or Kurtosis demonstrated in Figures 6 b1, b2, and b3, which leads to underestimation of the values of greater increment, between 6 and $10 \mathrm{~cm}$ of $\mathrm{DBH}$, and to overestimation of the increment between the 2 and $4 \mathrm{~cm}$ classes of $\mathrm{DBH}$ and between the 11 and $16 \mathrm{~cm}$ classes of $\mathrm{DBH}$ (depending on the population). These underestimations and overestimations, by the attempt of adequacy, produce non-random residuals, making the use of quadratic models inappropriate (degree 2) as shown in Figures 6 c1, c2, and c3.

For populations with few reproductive plants and few classes of higher DBH, as can be observed in younger species' populations or those with recent exploitation histories, as in UCAD, exposed in the Figure 3d, the use of second-degree polynomial models with a constant presented better results as demonstrated in Figures 6 a4, b4 and c4. The reason is related to the small participation of reproductive plants in population growth, making the models provided by secondand fifth-order polynomials very similar like the ones shown in Figures 6 b4 and c4, but unfavorable to the use of higherdegree polynomials $(>2)$ due to the low significance presented by the coefficients and/or non-random distribution of the residues. In this sense, the use of second-order polynomial models with a constant, or fifth-order ones with and without a constant, will depend greatly on the intended form of use for E. edulis. 

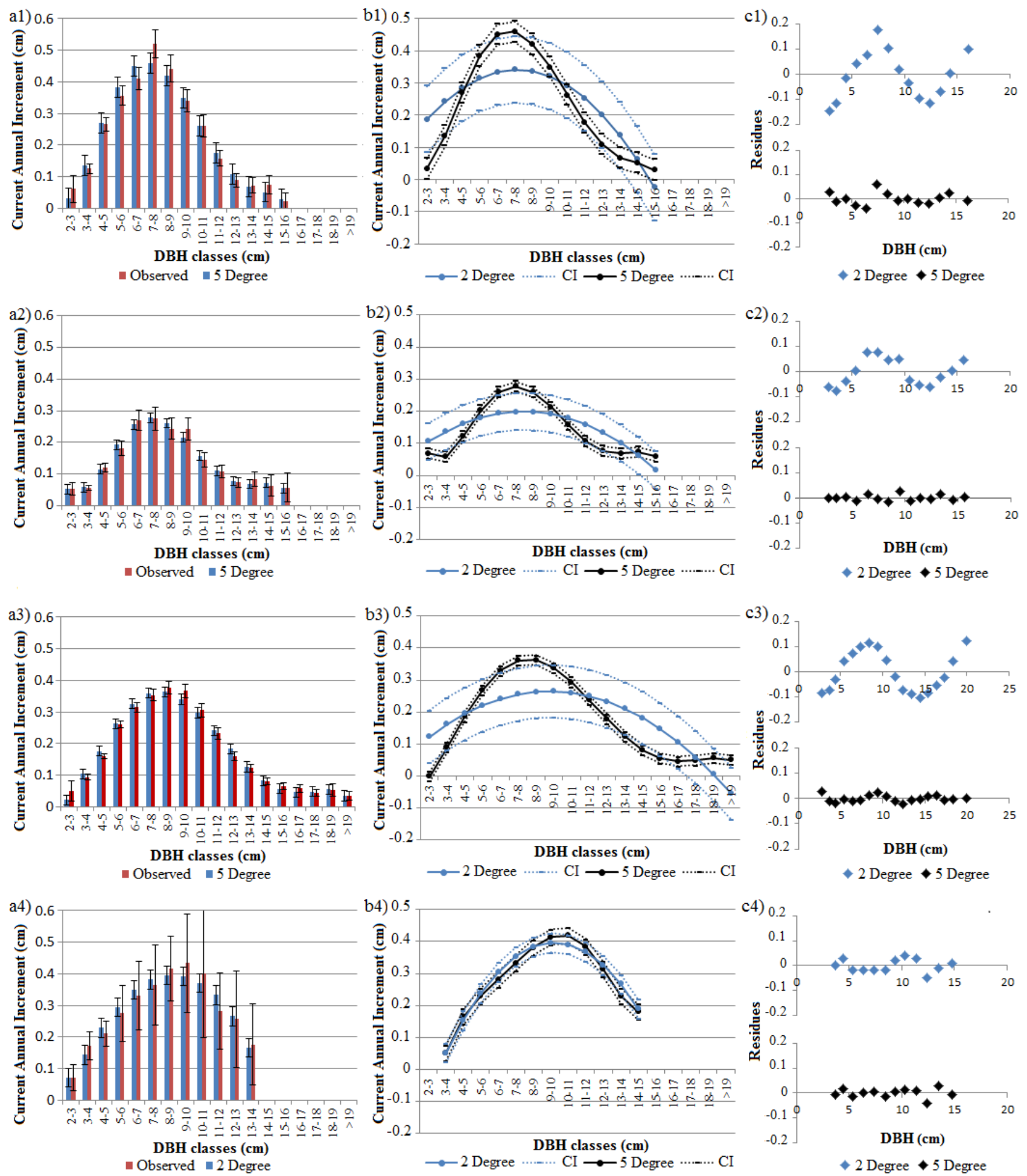

Figure 6. (a) Comparisons between the observed increments and those estimated by the polynomial models selected for the different study areas; (b) Comparisons between the increments estimated by second- and fifth-degree polynomials for the different study areas; (c) Comparisons between the residues obtained by the use of second- and fifth-degree polynomials for the different areas of study, where: (1) São Pedro de Alcântara - Mata Secundária, (2) São Pedro de Alcântara - Miconietum, (3) Flona-Ibirama; and (4) UCAD-Florianópolis. Error bars indicate $95 \%$ confidence intervals (CI). 


\section{CONCLUSIONS}

The curves of current annual increment in conserved populations of E. edulis, due to the higher number of reproductive palms and larger DBH classes, have positive asymmetry, its description being a necessary determinant of the adjustment and tested polynomial models choice.

When the use of mathematical models is geared towards ecological purposes, such as estimates related to population development or fruit management (Paludo et al., 2012; Silva \& Reis, 2018, 2019), the use of fifth-degree polynomial models with and without a constant presents better results, since it aims to describe the large-diameter plants' growth (above the higher CAI peaks). Such equations stand out for their superior capacity to adjust the positive asymmetry observed in populations in a better conservation state.

When the modeling objective involves managing populations of palm heart (Fantini \& Guries, 2007; Reis et al., 2000) or growth estimates in still young populations, in which few plants are present above the higher increment classes in DBH (between 6 and $10 \mathrm{~cm}$ ), the use of quadratic polynomial models with a constant is characterized as the most appropriate.

The woody tree species basal area interfered in the increment curves. Successively more advanced stages (higher basal area) lowered E. edulis increment rates, possibly related to competition in search of light and space. This fact is worth highlighting, because although $E$. edulis is considered a climax species, the reduction of its growth rate according to the succession advance suggests difficulties in maintaining productivity, as well as the possibility that populations exploited illegally or without criteria require more time to recover. These results corroborate observations from other studies, ranging from the identification of lower development and survival of $E$. edulis seedlings in more shaded environments to greater growth of young and greater reproductive palms' fertility when they are present in altered areas versus protected areas (Fantini \& Guries, 2007; Neuburger et al., 2010; Portela et al., 2010). Experiments on the response of E. edulis to reductions in the forest's basal area could provide important information regarding the maintenance of the observed growth rates at earlier stages.

The increment values were also affected by the reproductive activity, being greatly reduced in reproductive palms. The lower CAI values were even observed in plants that emitted more reproductive structures, which was also observed by Silva \& Reis (2018), who indicated a higher reproductive frequency in palms with higher DBHs. In this sense, it should be noted that the establishment of a cut limit diameter (CLD) for the definition of the moment of the harvest of the palm heart could limit the number of reproductive plants in sustainable systems. This would also hamper natural regeneration processes via potential reductions in crossing rates, genetic diversity, dispersal, fruit production, seeds and seedlings (Neuburger et al., 2010; Novello et al., 2018; Portela et al., 2010; Silva \& Reis, 2010, 2019).

\section{ACKNOWLEDGEMENTS}

To CNPq and FAPESC/Pronex for funding research and productivity scholarship of Maurício Sedrez dos Reis; to Capes for the postdoctoral fellowship of Juliano Zago da Silva; and to the Instituto Chico Mendes de Conservação da Biodiversidade (ICMBio), São Pedro de Alcântara City Hall and UCAD/UFSC Department of Botany, for making their areas available for the realization of studies.

\section{SUBMISSION STATUS}

Received: 8 Feb. 2018

Accepted: 22 Aug. 2018

Associate editor: Rodrigo Studart Corrêa

(D) 0000-0002-9422-2629

\section{CORRESPONDENCE TO}

\section{Juliano Zago da Silva}

Universidade Federal de Santa Catarina (UFSC), Centro de Ciências Agrárias, Rodovia Admar Gonzaga, 1346, Itacorubi, CEP 88034-000, Florianópolis, SC, Brasil

e-mail: jzagos@yahoo.com.br

\section{FINANCIAL SUPPORT}

Ministério da Ciência, Tecnologia e Inovação, Conselho Nacional de Desenvolvimento Científico e Tecnológico (CNPq) (Grant/Award: 304724/210-6). Coordenação de Aperfeiçoamento de Pessoal de Nível Superior (Capes) (Grant/Award: postdoctoral scholarship to Juliano Z. Silva - PNPD). Fundação de Amparo à Pesquisa e Inovação do Estado de Santa Catarina (Fapesc) (Grant/Award: PRONEX/2780/2012-4).

\section{REFERENCES}

Avalos G. Growth of the neotropical palm Euterpe precatoria (Arecaceae) under sun and shade conditions in an agroforestry system in Costa Rica. Brenesia 2016; 85(86): 1-10.

Brasil. Ministério do Meio Ambiente - MMA. Portaria MMA n. 443, de 18 de dezembro de 2014. Lista oficial das espécies da flora brasileira ameaçadas de extinção. Diário Oficial da República Federativa do Brasil, Brasília, DF (2014 Sept. 18); Sec. 245: 110-121. Botânico MP, Angyalossy V. Is the secondary thickening in palms always diffuse? Anais Academia Brasileira de Ciências 2013; 85(4): 1461-1472. 10.1590/0001-37652013108612 
Cappelatti L, Schmitt JL. Spatial distribution and population structure of palms (Arecaceae) in a forest fragment of lowland dense humid forest in south Brazil. Ciência Florestal 2015; 25(4): 817-825.

Cepeda-Cornejo V, Dirzo R. Sex-related differences in reproductive allocation, growth, defense and herbivory in three dioecious neotropical palms. PLoS ONE 2010; 5(3): e9824. 10.1371/journal. pone.0009824

Brasil. Conselho Nacional do Meio Ambiente - Conama. Resolução Conama 04/94, de 4 de maio de 1994. Diário Oficial da República Federativa do Brasil, Brasília, DF (1994 jun. 17); Sec. 1: 8877-8878.

Edwards PJ, Fleischer-Dogley F, Kaiser-Bunbury CN. The nutrient economy of Lodoicea maldivica, a monodominant palm producing the world's largest seed. New Phytologist 2015; 206(3): 990-999. 10.1111/nph.13272

Fantini AC, Guries RP. Forest structure and productivity of palmiteiro (Euterpe edulis Martius) in the Brazilian Mata Atlântica. Forest Ecology and Management 2007; 242(2-3): 185-194. 10.1016/j. foreco.2007.01.005

Fantini AC, Reis A, Reis MS, Guerra MP. Sustained yield management in tropical forest: a proposal based on the autoecology of the species. Sellowia 1992; 42-44: 25-33.

Galetti M, Guevara R, Cortes MC, Fadini R, Von Matter S, Leite $\mathrm{AB}$ et al. Functional extinction of birds drives rapid evolutionary changes in seed size. Science 2013; 340(6136): 1086-1090. 10.1126/ science. 1233774

Granville JJ. Life forms and growth strategy of Guianan palms. In: Palms in tropical forests. Cayenne: International Symposium, Iquitos; 1991. p. 1-26.

Guimarães LAOP, Souza RG, Dan ML, Guimarães MAD. Emergence and vigor of Euterpe edulis seedlings under shading levels and the presence and absence of the pericarp. Idesia 2018; 36(1): 49-56.

Instituto Chico Mendes de Conservação da Biodiversidade - ICMBio. Plano de Manejo Floresta Nacional de Ibirama Santa Catarina: informações gerais. Vol. 1. Brasília, DF: ICMBio; 2008. 158 p.

Klein RM. Flora e vegetação do Vale do Itajaí. Sellowia 1980; 32(32): 165-389.

Konzen ER, Martins MP. Contrasting levels of genetic diversity among populations of the endangered tropical palm Euterpe edulis Martius. Cerne 2017; 23(1): 31-42. 10.1590/01047760201723012237

Leite AB, Brancalion PHS, Guevara R, Galetti M. Differential seed germination of a keystone palm (Euterpe edulis) dispersed by avian frugivores. Journal of Tropical Ecology 2012; 28(6): 615-618.

Mantovani M, Ruschel AR, Puchalski A, Silva JZ, Reis MS, Nodari RO. Diversidade de espécies e estrutura sucessional de uma formação secundária da floresta ombrófila densa. Scientia Forestals 2005; 67:13-25.

Muler AE, Rother DC, Brancalion PS, Naves RP, Rodrigues RR, Pizo MA. Can overharvesting of a non-timber-forest-product change the regeneration dynamics of a tropical rainforest? The case study of Euterpe edulis. Forest Ecology and Management 2014; 324: 117-125.

Neuburger M, Souza TV, Paulilo MT. Crescimento inicial de plantas Euterpe edulis Mart. em diferentes condições de luz, água e nutrientes. Rodriguésia 2010; 61(2): 157-165. 10.1590/2175-7860201061201

Ninazunta M, Queenborough SA, Hernández C, Valencia R. Growth strategies of the arborescent palm Iriartea deltoidea in a western Amazonian forest. Botanical Journal of the Linnean Society 2016; 182(2): 411-424. 10.1111/boj.12448
Novello M, Viana JPG, Alves-Pereira A, Silvestre EA, Nunes HF, Pinheiro JB et al. Genetic conservation of a threatened neotropical palm through community-management of fruits in agroforests and second-growth forests. Forest Ecology and Management 2018; 407: 200-209. 10.1016/j.foreco.2017.06.059

Paludo GF, Silva JZ, Reis MS. Estimativas de produção de frutos de palmiteiro (Euterpe edulis Mart.) a partir da densidade de indivíduos. Biodiversidade Brasileira 2012; 2(2): 92-102.

Portela RCQ, Bruna EM, Santos FAM. Are protected areas really protecting populations? A test with an Atlantic rain forest palm. Tropical Conservation Science 2010; 3(4): 361-372.

Reis MS, Conte R, Fantini AC, Nodari RO. Caracterização do incremento em diâmetro de Euterpe edulis Mart. e implicações para o seu manejo em formações florestais secundárias. Revista Árvore 1999; 23(4): 413-422.

Reis MS, Fantini AC, Nodari RO, Guerra MP, Reis A. Sustained yield management of Euterpe edulis Martius (Palmae): a tropical palm tree from the Atlantic Tropical Forest. Journal of Sustainable Forestry 2000; 11(3): 1-17.

Ribeiro TM, Martins SV, Lana VM, Silva KA. Survival and initial growth of Euterpe edulis Mart. seedlings transplanted to gaps and undestory in a Semideciduous Forest, Viçosa, MG. Revista Árvore 2011; 35(6): 1219-1226. 10.1590/S0100-67622011000700008

Scheeren LW, Fleig FD, Schneider PR, Finger CAG. Crescimento de canela-lageana, Ocotea pulchella Nees et Mart. ex Nees, na depressão central do estado do Rio Grande do Sul. Ciência Florestal 2003; 13(1): 137-144. 10.5902/198050981732

Silva JZ, Reis MS. Consumption of Euterpe edulis fruit by wildlife: implications for conservation and management of the Southern Brazilian Atlantic Forest. Anais da Academia Brasileira de Ciências 2019; 91(1): e20180537. 10.1590/0001-3765201920180537

Silva JZ, Reis MS. Effects of different simulated management intensities on the genetic diversity of a heart-of-palm tree natural population (Euterpe edulis Martius). Silvae Genetica 2010; 59(5): 201-210. 10.1515/sg-2010-0024

Silva JZ, Reis MS. Fenologia reprodutiva e produção de frutos em Euterpe edulis (Martius). Ciência Florestal 2018; 28(1): 295-309. $10.5902 / 1980509831655$

Souza AF, Martins FR, Bernacci LC. Clonal growth and reproductive strategies of the understory tropical palm Geonoma brevispatha: an ontogenetic approach. Canadian Journal of Botany 2003; 81(2): 101-112. 10.1139/b03-002

Spathelf P, Berger R, Vaccaro S, Tonini H, Borsoi GA. Crescimento de espécies nativas de uma floresta estacional decidual/ombrófila mista do Rio Grande do Sul. Ciência Florestal 2001; 11(2): 103-119. $10.5902 / 198050981659$

Svenning JC. Crown illumination limits the population growth rate of a neotropical understorey palm (Geonoma macrostachys, Arecaceae). Plant Ecology 2002; 159(2): 185-199. 10.1023/A:1015520116260

Thomas SC. Age-Related changes in tree growth and functional biology: the role of reproduction. In: Meinzer FC, Lachenbruch B, Dawson TE, editors. Size- and age-related changes in tree structure and function. Heidelberg: Springer; 2011. p. 33-64.

Trevisan ACD, Fantini AC, Schmitt-Filho AL, Farley J. Market for Amazonian Açaí (Euterpe oleraceae) stimulates pulp production from Atlantic Forest Juçara Berries (Euterpe edulis). Agroecology and Sustainable Food Systems 2015; 39(7): 762-781. $10.1080 / 21683565.2015 .1025461$ 